\title{
Ontogeny of glutamate accumulating activity in rat brain synaptic vesicles
}

\author{
Phillip E. Kish ${ }^{1}$, Soo Y. Kim ${ }^{1}$ and Tetsufumi Ueda ${ }^{1,2}$ \\ 'Mental Health Research Institute and 'Departments of Pharmacology and Psychiatry. The University' of \\ Michigan, Ann Arbor, MI 48109 (U.S.A.)
}

(Received 9 September 1988; Revised version 11 October 1988; Accepted 11 October 1988)

Key words: Synaptic vesicle; Development: Synaptogenesis; Neurotransmitter; Glutamate; ATP-dependent uptake

The relationship between the ontogeny of the vesicular glutamate uptake system and synaptogenesis in rats was investigated. For this purpose we have developed a simplified procedure for the preparation of crude synaptic vesicles which are sufficiently pure to demonstrate a highly ATP-dependent glutamate uptake. ATP-dependent glutamate uptake into synaptic vesicles was found to increase dramatically starting on postnatal day 10 and reaching a maximum on day $30(76 \pm 40$ and $657 \pm 40 \mathrm{pmol} / \mathrm{mg}$ protein/10 min, respectively), correlating well with the active period of synaptogenesis. Stimulation of uptake by chloride also developed in parallel with the vesicular glutamate uptake. In contrast, combined non-ATPdependent uptake and non-specific binding remained constant $(21 \pm 6 \mathrm{pmol} / \mathrm{mg}$ protein $/ 10 \mathrm{~min})$. This development of vesicular glutamate uptake during the period of synaptogenesis supports the notion that synaptic vesicles play an important role in glutamate synaptic transmission.

A variety of evidence now strongly supports the notion that glutamate serves as an excitatory neurotransmitter in the central nervous system [4, 18]. Added to this growing body of evidence is the recent demonstration and detailed characterization of the ATP-dependent uptake of glutamate into synaptic vesicle preparations $[9,13$, 14]. Translocation of glutamate into the synaptic vesicle interior has been found to require a $\mathrm{Mg}^{2+}$-dependent proton-pumping ATPase located in the vesicle membrane. This ATP-dependent vesicular uptake system exhibits low affinity $\left(K_{\mathrm{m}} 2.2-2.8\right.$ $\mathrm{mM}$, in this preparation, data not shown), yet is highly specific for glutamate and markedly stimulated by low millimolar concentrations of chloride. It has been proposed that this glutamate-specific vesicular uptake system plays an important role in determining the neurotransmitter role of glutamate [23]. Nicholls and Sihra [16] have provided evidence that glutamate is released from a non-cytoplasmic pool in a calcium-dependent manner. This is compatible with the notion that synaptic vesicles are involved in the release of glutamate. We have recently obtained evidence that

Correspondence: T. Ueda. Mental Health Research Institute, The University of Michigan. 205 Washtenaw Place. Ann Arbor. MI 48109, U.S.A. 
the ATP-dependent glutamate uptake system is present in cerebellar granule cells [6]. which are considered to be glutamatergic, but not in GABAergic Purkinje cells. In an effort to provide further supporting evidence for the role of synaptic vesicles in glutamate transmission, we have investigated the ontogeny of the chloride-stimulated, ATP-dependent glutamate uptake system and compared it with the developmental time course of synaptogenesis. A preliminary account of this work has been reported previously [8].

Synaptic vesicles were prepared from rat cerebrum by the method of Kish and Ueda [9] at $4^{\circ} \mathrm{C}$. Pooled cerebra (approximately $1 \mathrm{~g}$ ) were homogenized in 10 volumes of solution A $(0.32 \mathrm{M}$ sucrose, $0.5 \mathrm{mM}$ calcium-acetate, $1 \mathrm{mM}$ magnesium-acetate, $1 \mathrm{mM} \mathrm{NaHCO}_{3}$ ), and the homogenate was centrifuged at $12,100 \mathrm{~g}_{\max }$ for $20 \mathrm{~min}$. The pellet was suspended with a Teflon rod in 20 volumes of ice-cold lysing solution ( $6 \mathrm{mM}$ Tris-maleate, $\mathrm{pH} \mathrm{8.1)} \mathrm{for} 45 \mathrm{~min}$ and centrifuged for $15 \mathrm{~min}$ at $43,000 \mathrm{~g}_{\text {max }}$. The resulting supernatant was centrifuged at $200,000 \mathrm{~g}_{\max }$ for $60 \mathrm{~min}$. The pelleted rat crude vesicles (RCSV) were resuspended in solution B $(0.32 \mathrm{M}$ sucrose, $1 \mathrm{mM}$ $\mathrm{NaHCO}_{3}, 1 \mathrm{mM}$ dithiothreitol). Protein was determined by the method of Lowry et al. [12] with bovine serum albumin as the standard.

Glutamate uptake was assayed essentially as described by Naito and Ueda [14], except that $2 \mathrm{mM}$ potassium aspartate was included in all the assay mixtures and the incubation time was extended to $10 \mathrm{~min}$. Steady-state levels for glutamate uptake are attained by this time [9]. The standard sucrose-based uptake medium (final volume, $100 \mu \mathrm{l}$ ) contained $0.25 \mathrm{M}$ sucrose, $4 \mathrm{mM} \mathrm{MgSO}$, $4 \mathrm{mM} \mathrm{KCl}, 5 \mathrm{mM}$ Trismaleate ( $\mathrm{pH}$ 7.4) and synaptic vesicles. After synaptic vesicles in the uptake medium $(80 \mu \mathrm{l})$ were incubated for $2 \mathrm{~min}$ at $30^{\circ} \mathrm{C}$, a pre-mixed solution of ${ }^{3} \mathrm{H}$-amino acid (final concentration, $50 \mu \mathrm{M} ; 0.4 \mathrm{Ci} / \mathrm{mmol}$ ) and ATP (final concentration, $2 \mathrm{mM}$; neutralized with Tris base) was added ( $20 \mu \mathrm{l})$, and the entire mixture was further incubated for $10 \mathrm{~min}$ at $30^{\circ} \mathrm{C}$. Amino acid uptake was stopped by the addition of ice-cold 0.15 $\mathrm{M} \mathrm{KCl}$ and immediate filtration and washing through Millipore HAWP (25 mm, $0.45 \mu \mathrm{m})$ filter. The radioactivity retained on the filters was determined using a liquid scintillation spectrophotometer. The synaptic vesicle glutamate translocator has been shown to be very selective for L-glutamate $[9,14]$, whereas the plasma membrane reuptake system $[2,11,24]$ and receptor binding $[5,7]$ recognize the amino acid Laspartate as well. We have found that the addition of high concentrations of L-aspartate (e.g. $2 \mathrm{mM}$ ) to the incubation solutions selectively blocks non-vesicular uptake and binding sites; this enables the assaying of ATP-dependent vesicular glutamate uptake in less purified vesicle preparations [9].

The activity of the vesicular Mg-ATPase was measured in the glutamate uptake assay buffer, by quantifying the release of orthophosphate from $\left[\gamma^{32} \mathrm{P}\right] \mathrm{ATP}$ according to the method of Nelson [15].

Fig. 1 shows the ATP-dependent glutamate uptake activity as a function of protein in the crude synaptic vesicle fractions from the cerebra of postnatal 10- and 60-dayold rats. The ATP-dependent uptake activity, either in the absence or presence of chloride, was proportional to the amount of protein between 40 and $80 \mu \mathrm{g}$ for the vesicle fractions prepared from either group. From these results a protein concentration of $50 \mu \mathrm{g}$ was selected for all further experiments. 

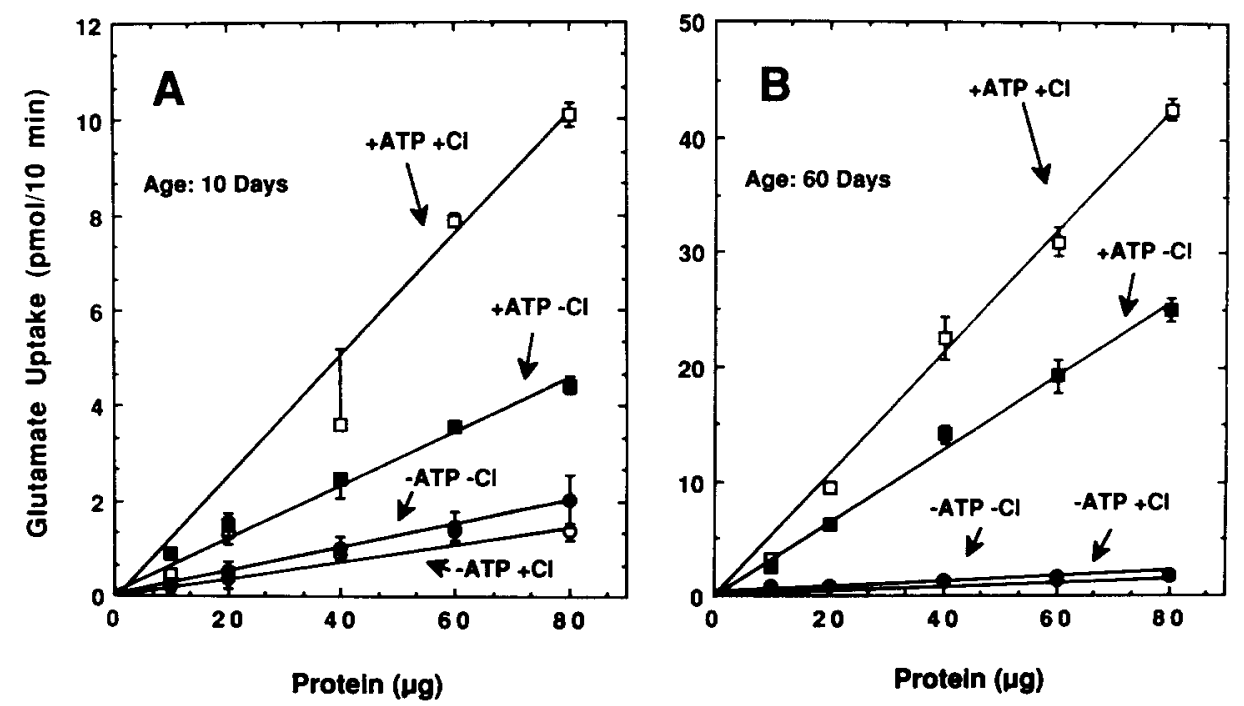

Fig. 1. Uptake of glutamate into rat crude synaptic vesicles as a function of amount of membrane protein. Cortical synaptic vesicles $\left(10 \cdots 50 \mu\right.$ g protein) were incubated at $30^{\circ} \mathrm{C}$ for $10 \mathrm{~min}$, in the presence or absence of Tris-ATP ( $2 \mathrm{mM})$ and potassium chloride $(4 \mathrm{mM})$, using the standard assay medium with $50 \mu \mathrm{M}$ tritiated glutamate. Rat crude synaptic vesicles were prepared from 10-day-old rats (A) and 60-day-old rats (B). The data represent the mean and S.D. of triplicate determinations. In a, we have fitted those data obtained with 40,60 and $80 \mathrm{mg}$ protein through the origin. The uptake activities observed at 10 and 20 $\mathrm{mg}$ protein from 10-day-old rats are too low to provide meaningful interpretation. The background filter binding gave $1.52 .0 \mathrm{pmol}$, which had been subtracted from all data.

Fig. 2 shows that the chloride-stimulated, ATP-dependent glutamate uptake system increases markedly (about 9 -fold) during the period between postnatal day 10 and day 30 (from $76 \pm 40$ to $657 \pm 40 \mathrm{pmol} / 10 \mathrm{~min} / \mathrm{mg}$ ). This developmental time course for the ATP-dependent glutamate uptake system correlates well with the time course of synaptogenesis in the rat brain, which was determined based on morphological criteria $[1,3]$. Since the ATP-dependency and chloride stimulation are characteristic of glutamate transport in the synaptic vesicle membrane, these data suggest that those synaptic vesicles which actively accumulate glutamate develop in parallel with general synaptogenesis, and therefore play an important role in synaptic function.

The marked development of the ATP-dependent glutamate uptake system could represent an increase in the Mg-dependent proton-pump ATPase or the glutamate translocator, or both, since any increase in ATPase activity could greatly potentiate glutamate transport. In order to distinguish between these possibilities, the $\mathrm{Mg}$ ATPase activity was measured as a function of age. Fig. 3 shows that the Mg-ATPase activity is increased only 2 -fold between day 10 and day 20 or 30 , which is in contrast to the much larger increase in activity for the ATP-dependent glutamate uptake between days 10 and 30 . These results suggest that increases in vesicular glutamate translocator quantity, rather than increases in the Mg-ATPase, would largely account for the increased uptake activity during the active period of synaptogenesis. 


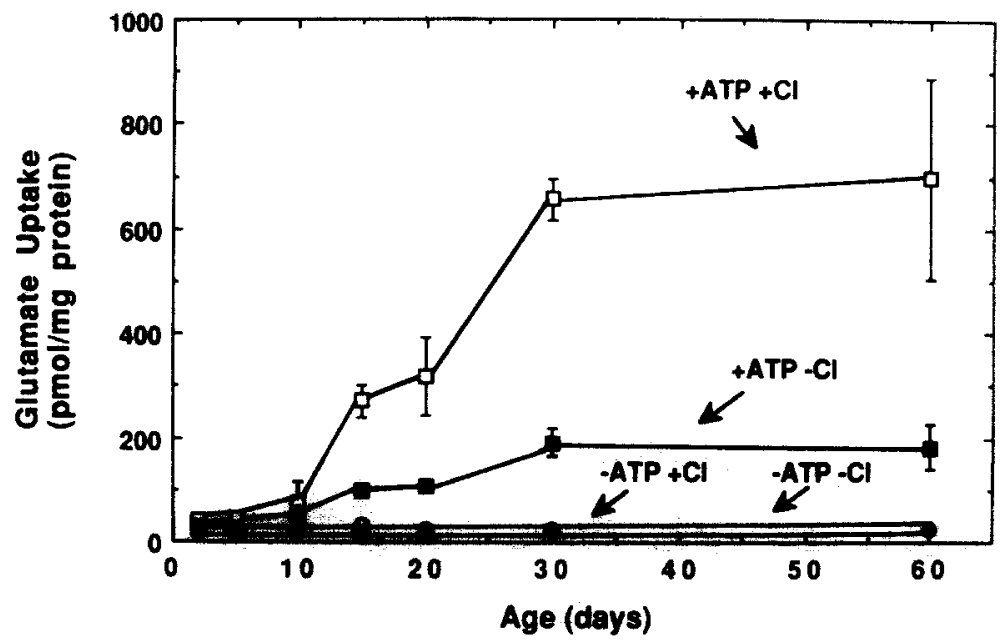

Fig. 2. Uptake of glutamate into rat crude synaptic vesicles during development from 2 to 60 days postnatal. Cortical synaptic vesicles $\left(50 \mu \mathrm{g}\right.$ protein) were incubated at $30^{\circ} \mathrm{C}$ for $10 \mathrm{~min}$, in the presence or absence of Tris-ATP ( $2 \mathrm{mM}$ ) and potassium chloride $(4 \mathrm{mM})$, using the standard assay medium with $50 \mu \mathrm{M}$ tritiated glutamate. Uptakes were determined using several preparations; the data represents the mean and standard deviations of 3 (days $2,5,10,15,20$ ) or 4 (days 30 and 60 ) experiments.

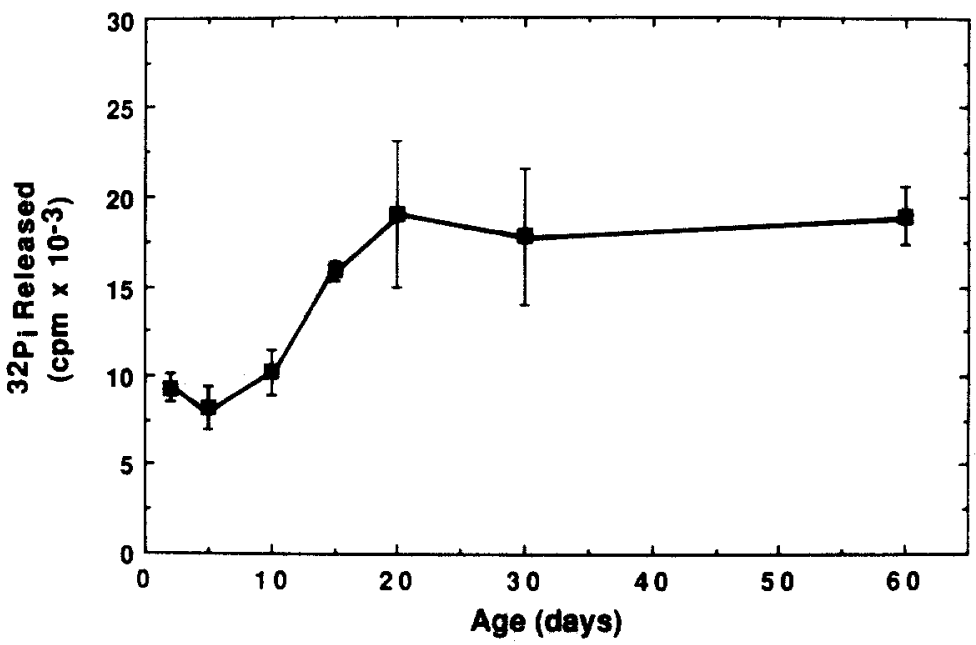

Fig. 3. Mg-ATPase activity in rat crude synaptic vesicles during development from 2 to 60 days postnatal. Cortical synaptic vesicles ( $50 \mu \mathrm{g}$ protein) were incubated at $30^{\circ} \mathrm{C}$ for $4 \mathrm{~min}$, in the presence of $\left[\gamma-{ }^{32} \mathrm{P}\right] \mathrm{ATP}$ $(2 \mathrm{mM})$ and potassium chloride $(4 \mathrm{mM})$, using the standard assay medium with $50 \mu \mathrm{M}$ unlabeled glutamate. Liberated [32P]phosphate was extracted and determined from equal volumes of the extract (1 ml). The data represent the mean and standard deviations of triplicate determinations.

However, establishing this will require further studies using an assay for directly quantifying the translocator.

It is interesting to note that synapsin I, a phosphoprotein associated at high con- 
centrations with synaptic vesicles, is also increased dramatically in parallel with synaptogenesis [10], although it is not involved in the vesicular glutamate transport [13]. Moreover, enzymes responsible for the formation of glutamate, such as glutamate dehydrogenase, aspartate aminotransferase, and alanine aminotransferase, have been shown to increase rapidly beginning the second week postnatal $[19,20$, 22]. The high-affinity plasma membrane reuptake system develops also with a strikingly similar time course [17]. Finally, sodium-independent binding of glutamate (considered to be binding to transmitter receptor sites) has been shown to develop between days 5 and 50 [21]. Thus, presynaptic and postsynaptic functional elements involved in glutamate synaptic transmission develop in parallel with synaptogenesis.

The pattern of increased ATP-dependent glutamate uptake observed during the active period of synaptogenesis suggests a functional role of the glutamate uptake system in the synapse. This is consistent with the hypothesis that sequestration of glutamate into synaptic vesicles is an important event in separating the role of glutamate as a neurotransmitter from its other roles in cell metabolism.

This study was supported by National Science Foundation Grant BNS-8207999. We are grateful to Mary Roth for excellent assistance in the preparation of the manuscript.

I Aghajanian, G.K. and Bloom, F.E., The formation of synaptic junctions in developing rat brain: a quantitative electron microscopic study, Brain Res., 6 (1967) $716-727$.

2 Balcar, V.J. and Johnston, G.A.R., The structural specificity of the high affinity uptake of L-glutamate and L-aspartate by rat brain slices, J. Neurochem., 19 (1972) 2656-2666.

3 Burry, R.W., Kniss, D.A. and Schribner, L.R., Mechanisms of synapse formation and maturation. In D.G. Jones (Ed.), Current Topics in Research on Synapses. Vol. I, Liss, New York, 1984, pp. 1 . 51.

4 Cotman, C.W., Monaghan, D.T., Ottersen, O.P. and Storm-Mathisen, J., Anatomical organization of excitatory amino acid receptors and their pathways, Trends Neurosci., 10 (1987) 273-279.

5 Fagg, G.E., Lanthorn, T.H., Foster, A.C., Maier, L., Dingwall, J., Lane, J.D. and Matus, A., Discrimination of excitatory amino acid receptor subtypes using radioligand binding techniques. In P.J. Roberts, J. Storm-Mathisen and H.F. Bradford (Eds.), Excitatory Amino Acids, Macmillan. London. 1986, pp. 263-277.

6 Fischer-Bovenkerk, C., Kish, P.E. and Ueda, T., ATP-dependent glutamate uptake into synaptic vesicles from cerebellar mutant mice, J. Neurochem., 51 (1988) 1054-1059.

7 Foster, A.C. and Fagg, G.E., Acidic amino acid binding sites in mammalian neuronal membranes their characteristics and relationship to synaptic receptors, Brain Res., 319 (1984) $103-164$.

8 Kish, P.E., Kim, S.Y. and Ueda, T., Ontogeny of the synaptic vesicle glutamate uptake system, Abstr. Trans. Am. Soc. Neurochem., 17 (1986) 219.

9 Kish, P.E. and Ueda, T., Glutamate accumulation into synaptic vesicles. In S. and B. Fleischer (Eds.), Methods in Enzymology, Biomembranes, Part M: Biological Transport, Vol. 4, Cellular and Sub-Cellular Transport: Eukaryotic (Non-Epithelial) Cells, Academic, New York, 1989, in press.

10 Lohman, S., Ueda, T. and Greengard, P., Ontogeny of synaptic phosphoproteins in brain, Proc. Nat1. Acad. Sci., U.S.A., 75 (1978) 4037-4041.

11 Logan, W.J. and Snyder, S.H., High affinity uptake systems for glycine, glutamic acid and aspartic acids in synaptosomes of rat central nervous tissues, Brain Res., 42 (1972) 413-431.

12 Lowry, O.H., Rosebrough, N.J., Farr, A.L. and Randall, R.J., Protein measurement with Folin phenol reagent, J. Biol. Chem., 193 (1951) 265-275.

13 Naito, S. and Ueda, T., Adenosine triphosphate-dependent uptake of glutamate into Protein I-associated synaptic vesicles, J. Biol. Chem., 258 (1983) 696699. 
14 Naito, S. and Ueda, T., Characterization of glutamate uptake into synaptic vesicles, 3. Neurochem.. 44 (1985) 99-109.

15 Nelson, N., Coupling factors from higher plants, Methods Enzymol., 69 (1980) $301-313$.

16 Nicholls, D.G. and Sihra, T.S., Synaptosomes possess an exocytotic pool of glutamate, Nature (Lond.), 321 (1986) 772-773.

17 Piccoli, F., Grynbaum, A. and Lajtha, A., Developmental changes in $\mathrm{Na}^{+}, \mathrm{K}^{+}$and ATP and in the levels and transport of amino acids in incubated slices of rat brain, J. Neurochem., 18 (1971) 1135 1148.

18 Robinson, M.B. and Coyle, J.T., Glutamate and related acidic excitatory neurotransmitters: from basic science to clinical application, FASEB J., I (1987) 446455.

19 Rothe, F., Schmidt, W. and Wolf, G., Postnatal changes in the activity of glutamate dehydrogenase and aspartate aminotransferase in the rat nervous system with special reference to the glutamate transmitter metabolism, Dev. Brain Res., 11 (1983) 67-74.

20 Rothe, F. and Wolf, G., Alanine aminotransferase in the rat nervous system during the postnatal development referring to the glutamate transmitter metabolism, Neurochem. Res., 9 (1984) $661-668$.

21 Sanderson, C. and Murphy, S., Glutamate binding in the rat cerebral cortex during ontogeny. Dev. Brain Res., 2 (1982) 329-339.

22 Schunzel, G., Wolf, G., Rothe, F. and Seidler, E., Histophotometric evaluation of glutamate dehydrogenase activity of the rat hippocampal formation during postnatal development, with special reference to the glutamate transmitter metabolism. Cell. Mol. Biol, 6 (1986) 31-42.

23 Ueda, T., Glutamate transport in the synaptic vesicle. In P.J. Roberts, J. Storm-Mathisen and H.F. Bradford (Eds.). Excitatory Amino Acids, Macmillan, London, 1986, pp. 173-195.

24 Wofsey, A.R., Kuhar, M.J. and Snyder, S.H., A unique synaptosomal fraction, which accumulates glutamic and aspartic acids, in brain tissue. Proc. Natl. Acad. Sci. U.S.A., 68 (1971) 11021106. 